\title{
DAMPAK TATA KELOLA PERUSAHAAN, TANGGUNG JAWAB SOSIAL PERUSAHAN DAN INTELECTUAL CAPITAL TERHADAP PROFITABILITAS PERUSAHAAN
}

\section{IMPACT OF CORPORATE GOVERNANCE, CORPORATE SOCIAL RESPONSIBILITY AND INTELLECTUAL CAPITAL ON COMPANY PROFITABILITY}

\author{
Nurul Qomariah ${ }^{1}$, Ni Nyoman Putu Martini' ${ }^{2}$ Hadi Paramu ${ }^{3}$ \\ Universitas Muhammadiyah Jember ${ }^{12}$, Universitas Jember ${ }^{3}$ \\ Email: nurulqomariah@unmuhjember.ac.id, ninyomanputu@unmuhjember.ac.id, \\ hadi.feb@unej.ac.id
}

\begin{abstract}
ABSTRAK
Tujuan dari penelitian ini adalah untuk mengetahui pengaruh tata kelola perusahaan, dan tanggung jawab sosial perusahaan serta intellectual capital terhadap profitabilitas pada perusahaan industry makanan yang tersertifikasi halal yang terdaftar di Bursa Efek Indonesia. Variabel yang digunakan adalah variabel bebas dan variabel terikat. Variabel terikatnya yaitu variabel profitabilitas. Variabel bebasnya adalah variable tata kelola perusahaan, tanggung jawab sosial perusahaan dan intellectual capital . Populasi penelitian adalah seluruh perusahaan industry makanan yang tersertifikasi halal yang terdaftar di Bursa Efek Indonesia dengan sampel yang memenuhi persyaratan ada 11 perusahaan. Metode analisis data yang digunakan adalah analisis regresi linier berganda, dengan bantuan software SPSS. Hasil penelitian menunjukkan bahwa tata kelola perusahaan tidak berpengaruh signifikan terhadap profitabilitas. Tanggung jawab sosial perusahaan tidak berpengaruh signifikan terhadap profitabilitas. Intellectual capital berpengaruh positif dan signifikan terhadap profitabilitas. Tata kelola perusahaan tidak berpengaruh signifikan terhadap profitabilitas.
\end{abstract}

Kata Kunci : tata kelola perusahaan yang baik, tanggung jawab sosial perusahaan, profitabilitas, modal intelektual

\begin{abstract}
The purpose of this study was to determine the effect of corporate governance, and corporate social responsibility and intellectual capital on profitability in halal certified food industry companies listed on the Indonesia Stock Exchange. The variables used are independent variables and dependent variables. The dependent variable is the variable profitability. The independent variables are corporate governance variables, corporate social responsibility and intellectual capital. The study population was all halal-certified food industry companies listed on the Indonesia Stock Exchange with 11 companies that met the requirements. The data analysis method used is multiple linear regression analysis, with the help of SPSS software. The results of the study indicate that corporate governance has no significant effect on profitability. Corporate social responsibility has no significant effect on profitability. Intellectual capital has a positive and significant effect on profitability. Corporate governance has no significant effect on profitability.
\end{abstract}

Keywords: good corporate governance, corporate social responsibility, profitability, intellectual capital. 


\section{PENDAHULUAN}

Sektor industri merupakan perusahaan yang memberikan sumbangan dalam Produk Domestik Bruto (PDB) nasional dan penerimaan devisa. Sektor industri mempunyai peranan penting dalam perekonomian Indonesia. Sektor industri diyakini sebagai sektor yang dapat memimpin sektor-sektor lain dalam sebuah perekonomian menuju kemajuan. Produk industri selalu memiliki terms of trade yang tinggi serta menciptakan nilai tambah yang lebih besar dibandingkan produk-produk lain. Hal ini disebabkan karena sektor industri memiliki variasi produk yang sangat beragam dan mampu memberikan manfaat yang tinggi kepada pemakainya. Kontribusi industri manufaktur diharapkan bisa naik menjadi $40 \%$ terhadap produk domestik bruto (PDB) dalam beberapa tahun ke depan. Kontribusi industri manufaktur terhadap PDB nasional 2015 mencapai 18,1\% dengan nilai Rp2.097,71 triliun, meningkat dibandingkan dengan 2014 yang hanya 17,8\% dengan nilai Rp1.884 triliun. Sektor industri pengolahan secara umum berkontribusi 20,84\% atau Rp2.405,4 triliun dari PDB nasional sebesar Rp11.540,79 triliun. Adapun dari capaian sektor pengolahan non migas, kontribusi terbesar masih disokong oleh industri makanan dan minuman sebesar 30,84\%. Selanjutnya disusul oleh industri barang logam, barang elektronik dan peralatan listrik $(10,81 \%)$, industri alat angkutan $(10,5 \%)$ serta industri kimia, farmasi dan obat tradisional $(9,98 \%)$.

Makanan dan minuman adalah kebutuhan utama yang dibutuhkan manusia baik secara kuantitatif maupun secara kualitatif. Bahan makanan pokok memegang peranan utama dalam memenuhi kebutuhan penduduk. Volume kebutuhan makanan dan minuman di Indonesia akan terus meningkat setiap tahunnya. Kecenderungan kenaikan ini disebabkan oleh faktor peningkatan pendapatan, pertambahan penduduk, dan meningkatnya kesadaran gizi yang seimbang. Kebutuhan makanan dan minuman semakin meningkat seiring dengan pertumbuhan penduduk Indonesia. Dari data yang ada terlihat bahwa sector makanan dan minuman memberikan sumbangan sebesar 30,84\% kepada produk domestik kotor. Dalam Undang-undang No. 33/2014 tentang Jaminan Produk Halal menyebutkan produk makanan, farmasi, dan kosmetika wajib menerapkan sertifikasi halal pada 2019. Adapun untuk makanan berlaku secara bertahap mulai 2017. Masalahnya, hal itu berlaku bagi semua produsen maupun importir. Permasalahan yang saat ini dihadapi adalah dari perusahaan sektor makanan dan minuman ada yang belum 
menerapkan sertifikasi halal bagi produknya, meskipun sudah ada undang-undang yang mengaturnya.

Permasalahan sertifikasi halal bagi industri makanan dan minuman penting untuk diperhatikan, hal ini karena mayoritas penduduk di Indonesia adalah sekitar 85\% menganut agama islam. Oleh karena itu perusahaan yang bergerak di sektor makanan dan minuman harus memperhatikan tentang pentingnya sertifikasi halal bagi produk makanan dan minuman yang diproduksinya karena hal ini akan mempengaruhi peningkatan keuntungan dan nilai perusahaan dari perusahaan tersebut. Banyak faktor yang dapat meningkatkan profitabilitas suatu perusahaan. Diantara faktor yang dapat meningkatkan profitabilitas antara lain tata kelola perusahaan yang baik, tangung jawab social perusahaan dan intellectual capital.

Rasio profitabilitas merupakan salah satu rasio dalam analisis laporan keuangan perusahaan. Rasio profitabilitas dapat diukur dengan menggunakan return on equity (ROE) dan return on asset (ROA). Return on Equity (ROE) merupakan suatu alat ukur dari penghasilan yang tersedia bagi para pemilik perusahaan baik para pemegang saham biasa ataupun saham preferen atas modal yang mereka investasikan di dalam perusahaan tersebut (Syamsudin, 2009). Return on Assets (ROA) merupakan rasio yang digunakan untuk mengukur kemampuan suatu perusahaan dalam memanfaatkan aktiva untuk memperoleh laba, sehingga apabila nilai ROA semakin tinggi maka dapat dikatakan semakin bagus kinerja perusahaan (Syamsuddin, 2009). Profitabilitas yang tinggi menunjukan prospek perusahaan yang baik, sehingga investor akan merespon positif sinyal tersebut dan nilai perusahaan akan meningkat. Profitabilitas dapat diukur melalui jumlah laba operasi, laba bersih, tingkat pengembalian investasi/aktiva, dan tingkat pengembalian ekuitas pemilik. Ang (2010) mengungkapkan bahwa rasio profitabilitas atau rasio rentabilitas menunjukan keberhasilan perusahaan dalam menghasilkan keuntungan. Profitabilitas dalam penelitian ini diukur dengan proksi Return on Equity (ROE).

Teori keagenan memberikan kerangka berpikir mengenai masalah tata kelola korporasi akibat terjadinya pemisahan antara kepemilikan dan pengendalian perusahaan. Jensen dan Mecling (1976) mengidentifikasikan dua cara untuk mengurangi kesempatan manajer melakukan tindakan yang merugikan investor yaitu investor luar melakukan pengawasan dan manajer sendiri melakukan pembatasan atas tindakan-tindakannya. Dalam prakteknya keberhasilan penerapan good corporate governance tidaklah semudah 
memahami konsepnya saja. Penerapan good corporate governance sebaik apapun bukanlah jaminan tidak akan timbul suatu penyimpangan kalau tidak ada integritas dan moralitas dari para pelakunya. Tidak jarang terjadi fenomena kesalahpahaman, kekurangtaatan, dan konflik peran serta fungsi pengambilan keputusan diantara pengelola perusahaan dan bahkan manipulasi keuangan oleh pihak direksi dan manajer. Kemungkinan hal tersebut terjadi karena adanya tindakan yang mementingkan diri sendiri dengan mengabaikan kepentingan investor sehingga menjatuhkan harapan investor tentang pengembalian atas investasi yang telah mereka tanamkan (Candra, 2015). Struktur kepemilikan di Indonesia memiliki karakteristik yang berbeda dari perusahaanperusahaan di negara lain. Sebagian besar perusahaan di Indonesia memiliki kecenderungan terkonsentrasi sehingga pendiri juga dapat duduk sebagai dewan direksi atau komisaris, dan selain itu konflik keagenan dapat terjadi antara manajer dengan pemilik dan juga antara pemegang saham mayoritas dan minoritas. Dalam sebuah tata kelola perusahaan, pemisahan kepemilikan dengan manajemen sering memberikan potensi terjadinya masalah keagenan. Salah satunya teori yang dipopulerkan oleh Jensen dan Meckling (1976), yaitu teori keagenan yang menganalisis hubungan antara prinsipal (pemilik) dan agen (manajer). Banyak penelitian yang menghubungkan antara tata kelola perusahaan dengan profitabilitas. Candra (2015) menyatakan bahwa tata kelola perusahaan berpengaruh negatif dan signifikan terhadap profitabilitas. Hasil penelitian Putra dan Nuzula (2017) menyatakan bahwa proporsi dewan komisaris independen, komite audit, kepemilikan manajerial, kepemilikan institusional secara simultan berpengaruh signifikan terhadap ROA namun tidak signifikan terhadap profitabilitas (ROE).

CSR merupakan bentuk pembangunan keberlanjutan perusahaan dengan bertanggungjawab terhadap sosial, ekonomi, dan lingkungan perusahaan akibat dari aktivitas operasional yang dilakukan perusahaan. Melalui pelaksanaan CSR diharapkan mampu memberikan dampak positif terhadap ekonomi, sosial dan lingkungan perusahaan (Untung ,2009:1). Perusahaan yang mampu memperhatikan lingkungan sekitar dengan mengalokasikan dananya untuk kegiatan sosial maka akan dikenal oleh masyarakat.

Tanggung jawab sosial perusahaan adalah mekanisme bagi suatu organisasi untuk secara sukarela mengintegrasikan perhatian terhadap lingkungan dan social ke dalam operasinya dan interaksinya dengan stakeholder, yang melebihi tanggungjawab organisasi di bidang hukum. Tanggung jawab sosial perusahaan sebagai kepedulian perusahaan yang menyisishkan sebagian keuntungannya bagi kepentingan pembangunan manusia dan lingkungan secara berkelanjutan 
berdasarkan prosedur yang tepat dan professional. Tanggungjawab social secara umum adalah dukungan manajemen terhadap kewajiban untuk mempertimbangkan laba, kepuasan pelanggan dan kesejahteraan masyarakat secara setara dalam mengevaluasi kinerja perusahaan. Hadi (2011) menjelaskan bahwa tingkat tanggungjawab social perusahaan memiliki dampak terhadap peningkatan kinerja ekonomi perusahaan, seperti: meningkatkan penjualan, legitimasi pasar, meningkatkan investor di pasar modal, meningkatkan nilai bagi kesejahteraan pemilik dan sejenisya. CSR dapat pula menurunkan biaya operasional perusahaan sehingga dapat menghemat pengluaran perusahaan, misalnya dengan menggunakan energi terbarukan atau menggunakan bahan-bahan daur ulang. Selain itu, penjualan produk dengan inovasi baru yang berpihak pada keramahan lingkungan atau berpihak pada keadaan masyarakat dapat menciptakan legitimasi sehingga masyarakat tertarik bahkan mampu untuk membeli produk kita. Pelaksanaan CSR juga sebagai bentuk usaha menjaga hubungan perusahaan dengan para stakeholders. Tanggung jawab sosial perusahaaan dalam penelitian ini, diukur dengan menggunakan Corporate Social Responsibility Disclosure Indexs (CSRDI) berdasarkan indikator Global Reporting Inisiatives (GRI). Indikator Global Reporting Inisiatives (GRI) terdiri dari 3 fokus pengungkapan yaitu ekonomi, lingkungan dan sosial sebagai dasar sustainability reporting. Indikator Global Reporting Inisiatives (GRI) dipilih karena merupakan aturan internasional yang telah diakui oleh perusahaan di dunia. Pengukuran Corporate Social Responsibility Disclosure Indexs (CSRDI) menggunakan contens analysis dalam mengukur variety dari CSRDI, contens analysis adalah salah satu metode pengukuran CSRDI yang sudah banyak digunakan dalam penelitian-penelitian sebelumnya. Penelitian yang menghubungkan tanggung jawab social perusahaan dengan peningkatan keungtungan adalah penelitian yang dilakukan oleh Rosdwianti dkk.(2016) yang menyatakan bahwa tanggungjawab social perusahaan berpengaruh signifikan terhadap profitabilitas ( ROE). Hasil penelitian Artisa dkk. (2015) menyatakan bahwa tanggungjawab social perusahaan tidak berpengaruh terhadap profitabilitas. Rahayu dkk. (2014) mengungkapkan bahwa tanggungjawab social berdapak terhadap profitabilitas yang diproxikan dengan ROA dan ROE.

Intellectual capital merupakan materi intelektual yang telah diformalisasikan, ditangkap, dan diungkit untuk menciptakan kekayaan, dengan menghasilkan suatu aset yang bernilai tinggi (Ulum, 2009). Intellectual capital merupakan sumber daya berupa pengetahuan yang tersedia 
pada perusahaan yang menghasilkan asset bernilai tinggi dan manfaat ekonomi di masa mendatang bagi perusahaan. Intellectual capital adalah suatu pengetahuan yang didukung proses informasi untuk menjalin hubungan dengan pihak luar. Intellectual capital mencakup semua proses dan menjadi asset tak berwujud dalam neraca meliputi merk dagang, paten dan merk. Intellectual capital sebagai kombinasi dari asset tidak berwujud meliputi pasar, intellectual property, sumber daya manusia, dan infrastruktur yang menjalankan fungsinya dalam perusahaan. Intellectual capital sebagai segala pengetahuan yang bersifat intelek, semua informasi, dan pengalaman yang digunakan perusahaan untuk menciptakan kesejahteraan. Dari semua definisi tersebut, intellectual capital dapat dianggap sebagai asset tidak berwujud yang dimiliki dan digunakan perusahaan untuk menghasilkan manfaat dan meningkatkan kesejahteraan.

Investasi dalam pelatihan dan peningkatan sumber daya manusia merupakan investasi yang amat penting karena pengalaman, skill, dan pengetahuan yang dimiliki sumber daya manusia mempunya nilai ekonomi bagi perusahaan yang menciptakan produktivitas dan kemampuan beradaptasi. Peningkatan produktivitas dari setiap pegawai atau human capital memerlukan biaya investasi pada human capital yang berkaitan dengan pemotivasian, pengawasan, dan mempertahankan pegawai dalam mengantisipasi return di masa mendatang. Indikator perusahaan telah mencapai tujuan, visi, dan misi biasanya dapat dilihat dari hasil kinerja dan nilai pasar perusahaan. Berbagai upaya dilakukan untuk mencapai hasil kinerja dan nilai pasar yang baik, terutama kinerja keuangan. Salah satu upaya yang dilakukan perusahaan saat ini dalam upaya mencapai kinerja dan nilai pasar yang baik yaitu mengembangkan sumberdaya manusia yang berkualitas, teknologi yang handal serta hubungan baik dengan pelanggan, yang merupakan elemen dari intellectual capital (Suhendah, 2012). Semakin besar nilai modal intelektuan (VAICTM) semakin efisien penggunaan modal perusahaan, sehingga menciptakan value added bagi perusahaan. Physical capital sebagai bagian dari modal intelektual menjadi sumber daya yang menentukan kinerja perusahaan. Selain itu, jika modal intelektual merupakan sumber daya yang terukur untuk peningkatan competitive advantages, maka modal intelektual akan memberikan kontribusi terhadap kinerja perusahaan. Modal intelektual diyakini dapat berperan penting dalam peningkatan nilai perusahaan maupun kinerja keuangan. Perusahaan yang mampu memanfaatkan modal intelektualnya secara efisien, maka nilai pasarnya akan meningkat. Penelitian Juanda (2016) menyatakan bahwa inteletual capital tidak berpengaruh terhadap 
profitabilitas. Kuspinta dkk.( 2018) menyatakan bahwa a Value Added Capital Employed (VACA) berpengaruh paling dominan terhadap profitabilitas perusahaan. Halim dkk. (2016) juga menyatakan bahwa terdapat pengaruh yang signifikan antara intellectual capital dengan tingkat keungtungan perusahaan. Marfuah dan Ulfa (2014) menyatakan bahwa human capital dapat meningkatkan profitabilitas. Capital Employed (VACA) mempunyai pengaruh signifikan terhadap profitabilitas (Hermanus dkk. 2013). Dari latar belakang dan kajian empiris yang sudah dilakukan maka tujuan yang ingin dicapai sehubungan dengan masalah yang dirumuskan adalah mengetahui pengaruh tata kelola perusahaan, tanggungjawab social perusahaan dan intectual capital terhadap profitabilitas perusahaan menggunakan indicator ROE pada perusahaan Industri Makanan Yang Tersertifikasi Halal Yang Terdaftar Di Bursa Efek Indonesia periode 2013 sampai dengan 2016.

\section{METODE PENELITIAN}

Dalam penelitian ini akan dianalisis pengaruh variabel-variabel tata kelola perusahan, tanggung jawab sosial perusahaan, dan intellectual capital terhadap profitabilitas. Untuk mengetahui pengaruh variabel-variabel tata kelola perusahan, tanggung jawab sosial perusahaan, dan intelectual capital terhadap profitabilitas secara individual digunakan uji $t$, dan untuk mengetahui pengaruh secara serempak digunakan uji F. Populasi sebagai wilayah generalisasi yang terdiri atas obyek/subyek yang mempunyai kuantitas dan karakteristik tertentu (Ghozali, 2006). Populasi penelitian ini adalah perusahaan manufaktur sector makanan dan minuman yang tersertifikasi halal listed di BEI pada tahun 2013-2016. Sampel perusahaan yang memenuhi persyaratan adalah sebanyak 11 perusahaan. Metode analisis statistic diskriptif digunakan untuk mengetahui statistif diskriptif yang terdiri dari nilai minimum, nilai maksimun, dan ratarata serta standar deviasi dari masing-masing variable yang ada. Uji asumsi klasik digunakan untuk menilai apakah di dalam sebuah model regresi linear Ordinary Least Square (OLS) terdapat masalah-masalah asumsi klasik. Uji asumsi klasik yang digunakan adalah uji heterokesdasitas, uji multikolinieritas, uji normalitas dan uji autokorelasi. Pengujian analisis jalur dengan pendekatan regresi linear berganda digunakan untuk mengetahui pengaruh variabel independen yang terdiri dari tata kelola perusahaan, tanggug jawab sosial perusahaan, dan intellectual capital terhadap variabel dependen yaitu profitabilitas. 


\section{HASIL DAN PEMBAHASAN}

\section{Hasil Statistik Diskriptif}

Variabel yang digunakan dalam penelitian ini adalah tata kelola Perusahaan $\left(\mathrm{X}_{1}\right)$, tanggug jawab sosial perusahaan $\left(\mathrm{X}_{2}\right)$, intellectual capital $\left(\mathrm{X}_{3}\right)$ dan , profitabilitas (Y). Hasil perhitungan menunjukkan bahwa Tata Kelola Perusahaan $\left(\mathrm{X}_{1}\right)$ yang diukur dengan proksi jumlah komite audit memiliki nilai minimum sebesar 0 orang (tidak ada komite audit) yaitu pada PT. Tri Banyan Tirta Tbk (ALTO) tahun 2013 dan 2014, sedangkan nilai maksimum sebesar 4 orang yaitu pada PT. Tiga Pilar Sejahtera Food Tbk. (AISA) tahun 2014-2016. Komite audit dalam Pedoman Umum Good Corporate Governance Indonesia dinyatakan bertugas untuk membantu dewan komisaris dengan memberikan pendapat profesional yang independen untuk meningkatkan kualitas kerja serta mengurangi penyimpangan pengelolaan perusahaan.

Tanggung Jawab Sosial Perusahaan $\left(\mathrm{X}_{2}\right)$ memiliki rata-rata sebesar 0,243. Tanggung Jawab Sosial Perusahaan memiliki nilai minimum sebesar 0,090 yaitu merupakan Tanggung Jawab Sosial Perusahaan pada PT. Tri Banyan Tirta Tbk (ALTO) tahun 2013 dan 2014, sedangkan nilai maksimum sebesar 0,577 merupakan Tanggug Jawab Sosial Perusahaan pada PT. Indofood Sukses Makmur Tbk. (INDF) tahun 2016. Semakin besar Corporate Social Responsibility Disclosure Index (CSRDI) perusahaan memberikan gambaran semakin besar tanggug jawab sosial perusahaan.

Intellectual Capital $\left(\mathrm{X}_{3}\right)$ memiliki rata-rata sebesar 0,043\%. Intellectual Capital memiliki nilai minimum sebesar 3,768 yaitu merupakan Intellectual Capital pada PT. Sekar Laut Tbk. (SKLT) tahun 2016, sedangkan nilai maksimum sebesar 20,369 merupakan Intellectual Capital pada PT. Mayora Indah Tbk. (MYOR) tahun 2015. Semakin besar pengungkapan Intellectual Capital dalam laporan keuangan dapat memberikan gambaran perusahaan dalam mencapai keunggulan kompetitif.

Profitabilitas (Y) yang diukur dengan proksi Return on Equity (ROE) memiliki rata-rata sebesar $14,65 \%$. Profitabilitas memiliki nilai minimum sebesar $-4,74 \%$ yaitu merupakan profitabilitas pada PT. Tri Banyan Tirta Tbk (ALTO) tahun 2015, sedangkan nilai maksimum sebesar 28,99\% merupakanpProfitabilitas pada PT. Sekar Bumi Tbk. (SKBM) tahun 2013. Semakin tinggi Return on Equity (ROE) maka semakin baik profitabilitas perusahaan, yang artinya semakin baik kemampuan perusahaan dalam menghasilkan laba bersih dengan menggunakan modal sendiri dan menghasilkan laba bersih yang tersedia bagi pemilik atau investor. 
Hasil analisis collinearity statistic dapat disimpulkan bahwa tidak terjadi multikolinieritas, karena didapat nilai $\mathrm{VIF}<10$, artinya tidak terjadi hubungan linier antara variabel bebas yang digunakan dalam model regresi. Berdasarkan grafik scatterplot sebagaimana ditunjukkan pada hasil perhitungan dapat dilihat bahwa tidak ada pola yang jelas, serta titik-titik menyebar di atas dan di bawah angka 0 maka tidak terjadi heteroskedastisitas. Sehingga dapat dinyatakan bahwa model regresi yang diperoleh baik persamaan I telah memenuhi asumsi heteroskedastisitas. Adapun hasil pengujian untuk uji autokoreasi dapat dilihat pada pengujian I dengan nilai DW sebesar 1,802 yang berarti terletak diantara $\mathrm{d}_{\mathrm{U}}<\mathrm{d}<4-\mathrm{d}_{\mathrm{U}}(1,600<1,802<2,400)$. Hal ini berarti model regresi baik untuk persamaan I tidak terdapat masalah autokorelasi. Berdasarkan hasil pengujian normalitas maka hasilnya dapat dinyatakan bahwa nilai unstandardized residual yang diperoleh dari analisis regresi memiliki angka signifikansi lebih besar dari 0,05. Sehingga model regresi layak dipakai karena telah memenuhi asumsi normalitas.

Pengujian analisis jalur dengan pendekatan regresi linear berganda berguna untuk mengetahui pengaruh variabel independen yang terdiri dari tata kelola perusahaan $\left(\mathrm{X}_{1}\right)$, tanggung jawab sosial perusahaan $\left(\mathrm{X}_{2}\right)$, dan intellectual capital $\left(\mathrm{X}_{3}\right)$ terhadap variabel dependen profitabilitas (Y).

\section{Table 1. Results of Multiple Linear Regression Analysis}

\begin{tabular}{llllc}
\hline $\begin{array}{l}\text { Independent } \\
\text { Variable }\end{array}$ & $\begin{array}{l}\text { Dependent } \\
\text { Variabel }\end{array}$ & $\begin{array}{l}\text { Koef. } \\
\text { Regresion }\end{array}$ & taccount & Sig. \\
\hline & Constants & 3,845 & 1,079 & 0,287 \\
PROFITABIL-ITY & GCG & 2,059 & 1,575 & $0,123^{\mathrm{TS}}$ \\
& CSR & 0,186 & 0,023 & $0,982^{\mathrm{TS}}$ \\
& IC & 0,496 & 2,090 & $0,043^{* *}$ \\
\hline
\end{tabular}

Sumber: Data Diolah.

Berdasarkan hasil analisis yang telah dilakukan untuk pengujian terhadap profitabilitas diperoleh hasil koefisien determinasi berganda $\left(\mathrm{R}^{2}\right)$ sebesar 0,240. Hal ini berarti $24,0 \%$ variasi perubahan Profitabilitas dipengaruhi oleh variabel tata kelola perusahaan, tanggung jawab sosial perusahaan, dan intellectual capital sedangkan sisanya sebesar $76,0 \%$ disebabkan oleh faktor lain yang tidak termasuk dalam persamaan regresi yang dibuat. 


\section{Pembahasan}

\section{Pengaruh Tata Kelola Perusahaan Terhadap Profitabilitas}

Hasil perhitungan menunjukkan bahwa variabel tata kelola perusahaan $\left(\mathrm{X}_{1}\right)$ mempunyai pengaruh positif namun tidak signifikan terhadap profitabilitas, nilai koefisien beta sebesar 2,059 dan didapat nilai t hitung sebesar 1,575 dimana nilai signifikansi $(\mathrm{P})>0,05$ yaitu 0,123. Secara statistik nilai koefisien beta positif menunjukkan adanya pengaruh yang searah yang berarti semakin besar nilai tata kelola perusahaan semakin besar profitabilitas. Sehingga tidak ditemukan bukti secara statitik signifikan bahwa besarnya tata kelola perusahaan berpengaruh terhadap profitabilitas $\left(\mathrm{H}_{1}\right.$ ditolak).

Hasil uji regresi menunjukkan variabel tata kelola perusahaan berpengaruh positif namun tidak signifikan terhadap profitabilitas dengan koefisien regresi sebesar 2,059. Hal ini berarti semakin baik tata kelola perusahaan, maka profitabilitas juga semakin menngkat. Diperolehnya hasil yang tidak signifikan pengaruh tata kelola perusahaan terhadap profitabilitas disebabkan tinggi atau rendahnya jumlah komite audit sebagai proksi dari tata kelola perusahaan dalam suatu perusahaan tidak berpengaruh terhadap profitabilitas perusahaan. Jumlah komite audit tidak dapat menjamin keefektifan kinerja komite audit dalam melakukan pengawasan terhadap profitabilitas perusahaan. Pembentukan dari komite audit dalam suatu perusahaan hanya atas dasar untuk pemenuhan regulasi yang mensyaratkan bahwa perusahaan harus membentuk komite audit. Penelitian ini tidak sejalan dengan penelitian Candra (2015) yang menyatakan bahwa tata kelola perusahaan berpengaruh negatif dan signifikan terhadap profitabilitas. Hasil penelitian ini sejalan dengan penelitian Putra dan Nuzula (2017) yang menyatakan bahwa proporsi dewan komisaris independen, komite audit, kepemilikan manajerial, kepemilikan institusional secara simultan berpengaruh signifikan terhadap ROA namun tidak signifikan terhadap profitabilitas (ROE).

2. Pengaruh Tanggug Jawab Sosial Perusahaan Terhadap Profitabilitas

Hasil peneitian menunjukkan bahwa variabel tanggung jawab sosial perusahaan $\left(\mathrm{X}_{2}\right)$ mempunyai pengaruh positif namun tidak signifikan terhadap profitabilitas, nilai koefisien beta sebesar 0,186 dan didapat nilai t hitung sebesar 0,023 dimana nilai signifikansi $(\mathrm{P})>0,05$ yaitu 0,982. Secara statistik nilai koefisien beta positif menunjukkan adanya pengaruh yang searah yang berarti semakin besar tanggug jawab 
sosial perusahaan semakin besar profitabilitas. Sehingga tidak ditemukan bukti secara statitik signifikan bahwa besarnya tanggug jawab sosial perusahaan berpengaruh terhadap Ppofitabilitas ( $\mathrm{H}_{2}$ ditolak).

Hasil uji regresi menunjukkan variabel tanggug jawab sosial perusahaan berpengaruh positif namun tidak signifikan terhadap profitabilitas dengan koefisien regresi sebesar 0,186. Hal ini berarti semakin besar tanggug jawab sosial perusahaan, maka profitabilitas juga semakin besar. Pengaruh yang tidak signfikan tanggug jawab sosial perusahaan terhadap profitabilitas disebabkan bahwa belum banyak perusahaan yang mengembangkan program CSR secara berkelanjutan. Hal ini dapat dilihat dari jumlah perusahaan yang memiliki struktur organisasi dan SDM yang mengelola CSR. Sehingga tak jarang program-program CSR lebih banyak yang jangka pendek dan tidak meminimalkan risiko operasi perusahaan, tetapi lebih banyak pada charity dan pencitraan 'secuil' kegiatan santunan atau bakti sosial. Pencitraan memang perlu dilakukan oleh perusahaan, dan telah menjadi bagian strategi bisnis. Namun pencitraan saja belum menjamin keberlanjutan bisnis. Selain itu, masih kurangnya tingkat kepedulian masyarakat dalam menilai program CSR. Artinya, sekalipun pengusaha telah melakukan kepedulian terhadap lingkungannya, tetapi bilamana masyarakat konsumen sebagai pemakai produk perusahaan tidak memiliki kepedulian terhadap lingkungannya, maka udaha tersebut tidak akan mempunyai dampak yang positif terhadap kinerja keuangan (profitabilitas) perusahaan. Penelitian ini tidak mendukung penelitian yang dilakukan oleh Rosdwianti dkk. (2016) yang menyatakan bahwa tanggung jawab sosial perusahaan berpengaruh signifikan terhadap profitabilitas (ROE). Penelitian ini sejalan dengan hasil penelitian Artisa dkk. (2015) menyatakan bahwa tanggung jawab social perusahaan tidak berpengaruh terhadap profitabilitas. Penelitian ini sejalan dengan penelitian Rahayu dkk. (2014) yang mengungkapkan bahwa tanggung jawab social berdampak terhadap profitabilitas yang diproksikan dengan ROA dan ROE.

\section{Pengaruh Intellectual Capital Terhadap Profitabilitas}

Berdasarkan hasil penelitian didapatkan variabel intellectual capital $\left(\mathrm{X}_{3}\right)$ mempunyai pengaruh postif dan signifikan terhadap profitabilitas, nilai koefisien beta sebesar 0,496 dan didapat nilai t hitung sebesar 2,090 dimana nilai signifikansi $(\mathrm{P})<0,05$ yaitu 0,043 . Secara statistik nilai koefisien beta positif menunjukkan adanya pengaruh searah yang berarti semakin besar intellectual capital semakin besar Profitabilitas. 
Sehingga ditemukan bukti secara statitik signifikan bahwa intellectual capital berpengaruh terhadap profitabilitas $\left(\mathrm{H}_{3}\right.$ diterima).

Hasil uji regresi menunjukkan variabel intellectual capital berpengaruh positif dan signifikan terhadap profitabilitas dengan koefisien regresi sebesar 0,496. Hal ini berarti semakin besar intellectual capital yang ditunjukkan melalui return on equity yang dimiliki perusahaan, maka profitabilitas juga semakin besar. Modal yang digunakan merupakan nilai aset yang berkontribusi pada kemampuan perusahaan untuk menghasilkan pendapatan. Sehingga apabila modal yang digunakan suatu perusahaan dalam jumlah yang relatif besar maka mengakibatkan total aset perusahaan tersebut juga relatif besar. Sehingga pendapatan perusahaan pun akan meningkat pula. Hal ini dapat meningkatkan laba atas sejumlah ekuitas yang dimiliki perusahaan yang diukur dengan ROE. Perusahaan telah berhasil meningkatkan produktivitas aset yang ada didalamnya, dimana total aset tersebut merupakan bagian dari intellectual capital yang merupakan intangible asset yang memiliki peran penting dalam kemajuan kinerja perusahaan. Jika semakin baik perusahaan mengelola komponen intellectual capital, menunjukkan semakin baik perusahaan mengelola aset. Bila perusahaan mampu mengelola aset dengan baik dan dapat menekan biaya operasional maka dapat meningkatkan nilai tambah dari hasil kemampuan intelektual perusahaan. Kuspinta dkk.( 2018) menyatakan bahwa a Value Added Capital Employed (VACA) berpengaruh paling dominan terhadap profitabilitas perusahaan. Halim dkk. (2016) juga menyatakan bahwa terdapat pengaruh yang signifikan antara intellectual capital dengan tingkat keungtungan perusahaan. Marfuah dan Ulfa (2014) menyatakan bahwa human capital dapat meningkatkan profitabilitas. Capital Employed (VACA) mempunyai pengaruh signifikan terhadap profitabilitas (Hermanus dkk. 2013). Penelitian ini tidak sejalan dengan penelitian Juanda (2016) yang menyatakan bahwa inteletual capital tidak berpengaruh terhadap profitabilitas.

\section{KESIMPULAN DAN SARAN}

Berdasarkan uraian-uraian yang telah diungkapkan pada pembahasan, maka dapat diambil beberapa kesimpulan sebagai jawaban atas pokok permasalahan yang diajukan dalam penelitian ini, yaitu: tata kelola perusahaan tidak berpengaruh signifikan terhadap profitabilitas. Perusahaan-perusahaan yang menjadi sampel dalam penelitian ini merupakan perusahaan yang sudah mendapat sertifikasi halal, dengan demikian tata 
kelola perusahaan ini sudah bagus sehingga tidak berdampak terhadap keuntungan perusahaan.

Tanggung jawab sosial perusahaan tidak berpengaruh signifikan terhadap profitabilitas. Perusahaan. Perusahaan yang sudah terkenal dan mempunyai label halal wajib baginya untuk peduli terhadap lingkungannya lewat program tanggung jawab social. Oleh karena itu program perusahaan yang diwujudkan dalam tanggung jawab social perusahaan tidak berdampak terhadap keuntungannnya. Intellectual Capital berpengaruh positif dan signifikan terhadap profitabilitas. Investasi pada sumber daya manusia yang diwujudkan dalam intellectual capital penting dilakukan oleh perusahaan karena terbukti dapat meningkatkan keuntungan perusahaan.

\section{Saran}

Dari hasil penelitian ini saran yang dapat direkomendasikan adalah hasil penelitian menyatakan bahwa intellectual capital berpengaruh signifikan terhadap profitabilitas. Intellectual capital hendaknya menjadi perhatian khusus bagi pihak manajer sehingga dapat mewujudkan keunggulan kompetitif perusahaan. Penelitian ini hanya menggunakan sampel pada perusahaan manufaktur sektor makanan dan minuman yang tersertifikasi halal listed di BEI, sehingga hasil penelitian tidak dapat digeneralisasi untuk seluruh perusahaan di Indonesia. Adanya keterbatasan ini, maka bagi penelitian yang akan datang dapat menggunakan sampel perusahaan pada industri lainnya misalnya sektor keuangan, industri dasar dan kimia, pertambangan, dan yang lain.

\section{DAFTAR PUSTAKA}

Ang, Robert. 2010. Buku Pintar Pasar Modal Indonesia 7th Edition. Jakarta Media Soft Indonesia.

Artisa, Devinta Angelia, Yeterina Nugrahanti, dan Ari Budi Kristanto. 2015. Pengaruh Corporate Social Responsibility (CSR) Terhadap Biaya Operasional Dan Profitabilitas (Studi Pada Perusahaan Tekstil dan Garment yang Terdaftar Di Bursa Efek Indonesia Tahun 2011-2012). Prosiding Seminar Nasional \& Call For Papers Fakultas Ekonomika Dan Bisnis Universitas Stikubank.

Brigham, EF and LC Gapenski. 2006. Fundamental of financial management. Jakarta: Salemba Empat.

Candra, Erik. 2015. Pengaruh Good Corporate Governance Terhadap Leverage Dan Profitabilitas Pada Perusahaan Property Dan Real Estate Di Indonesia. Jurnal Gema Aktualita. Vol. 4 No. 2, Desember. 
Ghozali, Imam. 2006. Structural equation modeling. Metode alternative dengan partial least squares. Semarang: Badan Penerbit Universitas Diponegoro.

Hadi, Nor. 2011. Corporate Social Responsibility. Yogyakarta: Graha Ilmu

Iskandar. Pengaruh Penerapan Corporate Social Responsibility Terhadap Profitabilitas Perusahaan. Forum Ekonomi; Volume 18 No 12016.

Jensen, M.C. and William H. M. (1976). Theory of The Firm : Managerial Behavior, Agency Costs and Ownership Structure. Journal of Financial Economics, 3,305360. Journal Management Governance, 14,145-166 Journal of Business Research, 61,609-614.

Juanda, Rista Elva, Epi Fitriah, dan Yuni RRosdiana. 2016. Pengaruh Intectual Capital Terhadap Profitabilitas (ROA). Prosiding Akuntansi. Vo. 2 No. 1.

Kuspinta, Tuffahati Dhiagriya dan Achmad Husaini. 2018. Pengaruh Intellectual Capital Terhadap Profitabilitas Perusahaan (Studi Pada Perusahaan Manufaktur yang Terdaftar di Bursa Efek Indonesia Periode Tahun 2014-2016). Jurnal Administrasi Bisnis (JAB) Vol. 56 No. 1 Maret 2018 administrasibisnis.studentjournal.ub.ac.id

Putra, Agung Santoso dan Nila Firdausi Nuzula, 2017, Pengaruh Corporate Governance Terhadap Profitabilitas (Studi Pada Perusahaan Perbankan yang Terdaftar di Bursa Efek Indonesia Periode 2013-2015), Jurnal Administrasi Bisnis (JAB) $\begin{array}{lll}\text { Vol. } & 47 & \text { No.1 }\end{array}$ administrasibisnis.studentjournal.ub.ac.id

Rosdwianti, Mega Karunia, Moch. Dzulkirom AR, dan Zahroh Z.A. 2016. Pengaruh Corporate Social Responsibility (Csr) Terhadap Profitabilitas Perusahaan (Studi Pada Sektor Industri Barang Konsumsi Yang Terdaftar Di Bursa Efek Indonesia Periode 2013-2014). Jurnal Administrasi Bisnis (JAB) Vol. 38 No.2 September 2016

administrasibisnis.studentjournal.ub.ac.id

Suhendah. Rousilita. 2012. Pengaruh Intellectual Capital Terhadap Profitabilitas, Produktivitas, Dan Penilaian Pasar Pada Perusahaan Yang Go Public Di Indonesia Pada Tahun 2005-2007. Laporan Penelitian Universitas Tarumanegara.

Syamsuddin, Lukman. 2009. Manajemen Keuangan Perusahaan. Jakarta: PT. Raja Grafindo Persada.

Ulum, Ihyaul. 2009. Intelectual Capital: Konsep dan Kajian Empiris. Graha Ilmu. Yogyakarta.

Untung, Budi Hendrik. 2009. Corporate Social Responsibility. Jakarta: Sinar Grafika. 
Untung, U. 2010. Pengaruh Implementasi Good Corporate Governance Terhadap Return Saham Melalui Profitabilitas dan Likuiditas.Jurnal Ekonomi Bisnis. Universitas Gunadarma. Jakarta.

Wiwik Rahayu, Darminto, dan Topowijono. 2014. Pengaruh Pengungkapan Corporate Social Responsibility (CSR) Terhadap Profitabilitas Perusahaan (Studi Pada Perusahaan Sektor Pertambangan Periode 2012-2013 yang Terdaftar di Bursa Efek Indonesia). Jurnal Administrasi Bisnis (JAB) Vol. 17 No. 2 Desember. administrasibisnis.studentjournal.ub.ac.id 